\title{
Correlation of gene polymorphisms of vascular endothelial growth factor with grade and prognosis of lung cancer
}

\author{
Changjiang Liu', Xuetao Zhou², Zefeng Zhang ${ }^{1}$ and Yang Guo ${ }^{1 *}$ (D)
}

\begin{abstract}
Background: Vascular endothelial growth factor (VEGF) gene is highly polymorphic, and single nucleotide polymorphisms (SNP) of VEGF gene are associate with cancer prognosis. This study aimed to analyze the correlation of VEGF gene polymorphisms with grade and prognosis of lung cancer.

Methods: A total of 458 Chinese patients with primary lung cancer were enrolled from September 2008 to October 2013. The genotypes of $-2578 \mathrm{C}>\mathrm{A},-1154 \mathrm{G}>\mathrm{A},-460 \mathrm{~T}>\mathrm{C}$, and $+405 \mathrm{G}>\mathrm{C}$ were analyzed in white blood cells from patients using polymerase chain reaction based restriction fragment length polymorphism.
\end{abstract}

Results: Our data showed that $-1154 \mathrm{G}>$ A polymorphism was significantly associated with tumor stages, but all four tested VEGF gene polymorphisms had no significant effect on survival.

Conclusions: VEGF polymorphisms may relate to stage of lung cancer in Chinese population.

Keywords: Vascular endothelial growth factor, Single nucleotide polymorphism, Tumor stage, Tumor prognosis

\section{Background}

Angiogenesis, the formation of new blood vessels from endothelial precursors, represents a crucial process in the growth and progression of numerous solid malignancies [1-3]. Therefore, the molecular mechanism of tumorrelated angiogenesis has been of particular interest in the field of cancer research. The vascular endothelial growth factor A (VEGF-A) has been well identified as one of the key regulators of this process $[4,5]$. Clinical studies have revealed that the VEGF-A pathway is associated with the angiogenesis grade and disease outcome for various solid tumors, including lung cancer [6, 7]. High VEGF-A in tumor tissue or in serum have proved to be related to advanced tumor stage and prognosis of non-small cell lung cancer [8-10]. In addition, VEGF-A expression has found

\footnotetext{
* Correspondence: quoyang190421@163.com

'Department of Thoracic Surgery, the Fourth Hospital of Hebei Medical University, 12 Jiankang Road, Shijiazhuang 050000, China

Full list of author information is available at the end of the article
}

to be markedly higher in adenocarcinomas than in squamous-cell carcinomas [8].

The VEGF-A gene is assigned to chromosome 6p21.1, and constitutes a highly polymorphic gene. Numerous single nucleotide polymorphisms (SNPs) have been recognized in the promoter, $5^{\prime}$-, and $3^{\prime}$-untranslated regions (UTR) of the VEGF-A gene [11, 12]. Importantly, clinical studies have revealed that VEGF SNPs are associated with the production and function of VEGF, and subsequently, have an impact on cancer risk and prognosis. For example, patients with lung cancer carrying $2578 \mathrm{C} / \mathrm{C},-1154 \mathrm{~A} / \mathrm{A}$ and $\mathrm{G} / \mathrm{A}$, and $450 \mathrm{G} / \mathrm{G}$ genotypes have low VEGF expression, whereas high VEGF expression was detected in samples from patients carrying the $-2578 \mathrm{C} / \mathrm{A},-1154 \mathrm{G} / \mathrm{G}$, and $450 \mathrm{G} / \mathrm{C}$ genotypes [13]. In our previous study, we analyzed the relationship between four VEGF SNPs (including $-2578 \mathrm{C}>\mathrm{A},-1154 \mathrm{G}>\mathrm{A}$, $460 \mathrm{~T}>\mathrm{C}$, and $+405 \mathrm{G}>\mathrm{C}$ ) and risk of lung cancer, and found that $\mathrm{C}$ allele of $+405 \mathrm{G}>\mathrm{C}$ was significantly

(c) The Author(s). 2020 Open Access This article is licensed under a Creative Commons Attribution 4.0 International License, which permits use, sharing, adaptation, distribution and reproduction in any medium or format, as long as you give appropriate credit to the original author(s) and the source, provide a link to the Creative Commons licence, and indicate if changes were made. The images or other third party material in this article are included in the article's Creative Commons licence, unless indicated otherwise in a credit line to the material. If material is not included in the article's Creative Commons licence and your intended use is not permitted by statutory regulation or exceeds the permitted use, you will need to obtain permission directly from the copyright holder. To view a copy of this licence, visit http://creativecommons.org/licenses/by/4.0/. The Creative Commons Public Domain Dedication waiver (http://creativecommons.org/publicdomain/zero/1.0/) applies to the data made available in this article, unless otherwise stated in a credit line to the data. 
associated with increased risk of lung cancer in males [14]. In this study, we studied the correlation of these SNPs with grade and prognosis of lung cancer.

\section{Methods}

\section{Patients and samples}

This study was approved by the Ethics Committee of the Fourth Affiliated Hospital of Hebei Medical University. Peripheral white blood cells were collected from 458 Chinese patients who had pathologically diagnosed as lung cancer at the Department of Thoracic Surgery, the Fourth Affiliated Hospital of Hebei Medical University from September 2008 to October 2013. The staging of lung cancer was assessed according to the WHO classifications. Information including age, sex, smoking history, site of disease, histopathological type, stage, and therapy was collected from all the patients. Written informed consent was obtained from all participants.

\section{Genotyping of VEGF gene polymorphisms}

The genomic DNA was extracted from the peripheral white blood cells of patients using a genomic DNA purification kit (Promega). The genotypes of $-2578 \mathrm{C}>\mathrm{A}$ (rs699947), $-1154 \mathrm{G}>\mathrm{A} \quad(\mathrm{rs} 1570360), \quad-460 \mathrm{~T}>\mathrm{C} \quad(\mathrm{rs} 833061)$, and + 405G > C (rs2010963) were then analyzed using polymerase chain reaction (PCR) based restriction fragment length polymorphism (RFLP) as described in our previous study. The position of 4 VEGF SNPs relative to translation start site was shown in Fig. 1. The primers used were: (1) $-2578 \mathrm{C}>\mathrm{A}$ F: 5'-CCTAGCACCTCCACCAAACCA-3'; -2578C > A R: 5' CAGGGAACAAAGTTGGGGCTC-3'; $233 \mathrm{bp} ; \quad$ (2) -115 4G > A F: 5'-GGCGGATGGGTAATTTTCAGG-3'; -11 54G > A R: 5'-TCCCCGCTACCAGCCGACTTT-3'; 236 bp; (3) $-460 \mathrm{~T}>\mathrm{C}$ F: 5 '-TGAATGG AGCGAGCAGC GTCT-3'; $-460 \mathrm{~T}>\mathrm{C} \quad \mathrm{R}: \quad$ 5'-CGTGCGGACAGGGCCT GAGA-3'; 236 bp; (4) +405G > C F: 5'-TGTGGATTTT GGAAACCAGCAGA-3'; +405G > C R:5'-CGGTGTCTGT CTGTCTGTCCG-3'; 234 bp. Restriction enzyme used were: (1) -2578 C > A BglII; (2) -1154 G > A BglII; (3) -460 T > C Bs1236I; (4) +405G > C BglII. The expected result for each allele were: (1) $-2578 \mathrm{C}>\mathrm{A}$ : C/A genotype, $324 \mathrm{bp}, 202 \mathrm{bp}$ and $122 \mathrm{bp} ; \mathrm{C} / \mathrm{C}$ genotype, $324 \mathrm{bp} ; \mathrm{A} / \mathrm{A}$ genotype, $202 \mathrm{bp}$ and $122 \mathrm{bp}$. (2) -1154G > A: G/A genotype, $164 \mathrm{bp}$ and 150 bp; G/G genotype, 150 bp; A/A genotype, 164 bp. (3) -460 $\mathrm{T}>\mathrm{C}$ : T/C genotype, $175 \mathrm{bp}$ and $155 \mathrm{bp}$; C/C genotype, 155 bp; T/T genotype, 175 bp. (4) +405G > C: G/C genotype, 304 bp, 193 bp and 111 bp; C/C genotype, 304 bp; G/G genotype, $193 \mathrm{bp}$ and $111 \mathrm{bp}$.

\section{Statistical analysis}

The genotypes for each SNP were analyzed as a threegroup categorical variable. The differences in histopathological type, stage, or smoking year according to the four VEGF gene polymorphisms were compared using Chi square test or Fisher's Exact Test, while the differences in overall survival (OS) were analyzed using log-rank tests. Cox proportional hazard regression model was used for the multivariate survival analyses, and the analyses were always adjusted for age, sex, smoking, histopathological type, stage, and therapy. Statistical analysis was done with SAS 9.3, and a cutoff $P$ value of 0.05 was adopted for all analyses.

\section{Results}

\section{Patient characteristics}

A total of 458 patients with lung cancer were enrolled in this study. The age of the patients was $59.54 \pm 9.30$ years, and $320(69.87 \%)$ patients were male, and $223(48.69 \%)$ patients were smokers. The histopathological types of tumors included squamous cell carcinoma $(n=158$, $34.50 \%)$, adenocarcinoma $(n=215,46.94 \%)$, adenoacanthoma $(n=30,6.55 \%)$, and others $(n=54,12.01 \%)$. The tumor stages were as follows: stage I $(n=108$, $23.58 \%)$, stage II $(n=163,35.59 \%)$, stage III $(n=148$, $32.31 \%)$, and stage IV $(n=49,8.52 \%)$. During the 5 years of follow-up, 138 (30.13\%) patients survived, and 300 (65.50\%) patients died, and $20(4.37 \%)$ patients were lost to follow-up.

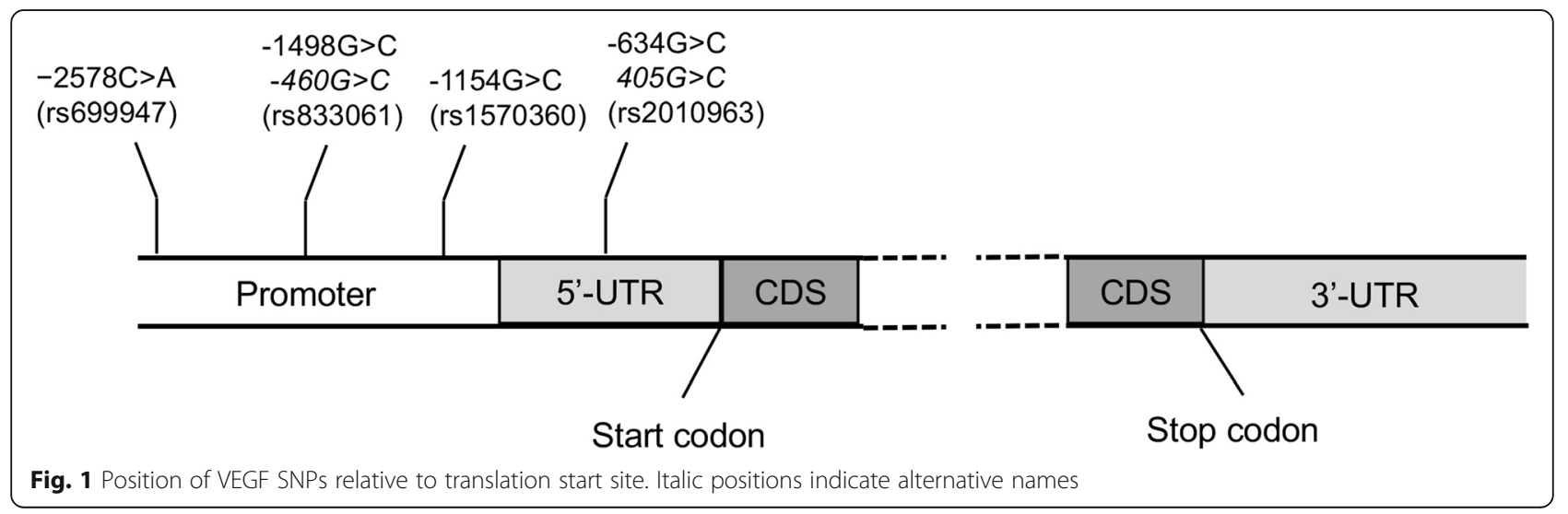


Table 1 Frequency distribution of VEGF genotypes in different histopathological types of lung cancer

\begin{tabular}{|c|c|c|c|c|c|}
\hline Variables & $\begin{array}{l}\text { Squamous cell carcinoma } \\
(n=158)\end{array}$ & $\begin{array}{l}\text { Adenocarcinoma } \\
(n=215)\end{array}$ & $\begin{array}{l}\text { Adenoacanthoma } \\
(n=30)\end{array}$ & $\begin{array}{l}\text { Others } \\
(n=55)\end{array}$ & $\begin{array}{l}\boldsymbol{P} \\
\text { value }\end{array}$ \\
\hline$-2578 \mathrm{C}>\mathrm{A}(\%)$ & & & & & 0.964 \\
\hline AA & $10(6.33)$ & $11(5.12)$ & $1(3.33)$ & $2(3.64)$ & \\
\hline$A C$ & 65 (41.14) & $82(38.14)$ & $12(40.00)$ & $23(41.82)$ & \\
\hline CC & $83(52.53)$ & $122(56.74)$ & $17(56.67)$ & $30(54.55)$ & \\
\hline$-1154 G>A(\%)$ & & & & & 0.814 \\
\hline$A A$ & $5(3.16)$ & $4(1.86)$ & $0(0.00)$ & $1(1.82)$ & \\
\hline$A G$ & $50(31.65)$ & $56(26.05)$ & $8(26.67)$ & 17 (30.91) & \\
\hline GG & $103(65.19)$ & 155 (72.09) & $22(73.33)$ & 37 (67.27) & \\
\hline$-460 \mathrm{~T}>\mathrm{C}(\%)$ & & & & & 0.969 \\
\hline $\mathrm{CC}$ & $0(6.33)$ & $12(5.58)$ & $1(3.33)$ & $2(3.64)$ & \\
\hline CT & 65 (41.14) & $82(38.14)$ & $12(40.00)$ & $23(41.82)$ & \\
\hline$\pi$ & 83 (52.53) & $121(56.28)$ & $17(56.67)$ & $30(54.55)$ & \\
\hline$+405 G>C(\%)$ & & & & & 0.990 \\
\hline $\mathrm{CC}$ & 29 (18.35) & 42 (19.53) & 7 (23.33) & $9(16.36)$ & \\
\hline$C G$ & $81(51.27)$ & $108(50.23)$ & $14(46.67)$ & $30(54.55)$ & \\
\hline GG & 48 (30.38) & $65(30.23)$ & $9(30.00)$ & $16(29.09)$ & \\
\hline
\end{tabular}

\section{Genotype frequency}

The four VEGF gene polymorphisms were successfully amplified in all cases. The frequencies of the genotypes were $5.24 \%(\mathrm{AA}), 39.74 \%(\mathrm{AC})$, and $55.02 \%(\mathrm{CC})$ for VEGF $-2578 \mathrm{C}>\mathrm{A} ; \quad 2.18 \%$ (AA), 28.60\% (AG), and 69.21\% (GG) for VEGF -1154G > A; 5.46\% (CC), 39.74\% (CT), and $54.80 \%$ (TT) for VEGF $-460 \mathrm{~T}>\mathrm{C} ; 19.00 \%$ (CC), $50.87 \%$ (CG), and $30.13 \%$ (GG) for VEGF $+405 \mathrm{G}>\mathrm{C}$; all were consistent with Hardy-Weinberg equilibrium $(P=0.32, P=0.50, P=0.26$, and $P=0.57$ respectively).

\section{Genotype effects on tumor histopathological types and stages}

Table 1 revealed that the proportions of all four VEGF gene polymorphisms were similar in different histopathological types of the tumor, which was consistent with our previous study. Table 2 showed that the $1154 \mathrm{G}>\mathrm{A}$ polymorphism instead of other SNP genotypes was significantly associated with tumor stages $(P=$ 0.042 ). Specifically, the proportion of A allele (AA and AG) was higher in the stage IV group $(48.71 \%)$ compared to other stage groups (stage I, 34.26\%; stage II, 26.38\%; stage III, 28.38\%). Smoking is the leading risk factor for lung cancer. Interestingly, Table 3 displayed that smoking status seemed to effect only on the distribution of $-1154 \mathrm{G}>\mathrm{A}$ polymorphism in patients $(P=$ 0.060). The proportion of $\mathrm{A}$ allele (AA and AG) was higher in the patients with more than 25 years of smoking $(38.60 \%)$ compared to non-smoking patients
(26.39\%) or patients with less than 25 years of smoking (25.00\%).

\section{Genotype effects on survival}

All four tested VEGF gene polymorphisms had no significant effect on survival in the univariate or

Table 2 Frequency distribution of VEGF genotypes in different stages of lung cancer

\begin{tabular}{llllll}
\hline Variables & I & II & III & IV & $\begin{array}{l}P \\
(n=108)\end{array}$ \\
& $(n=163)$ & $(n=148)$ & $(n=39)$ & value \\
\hline$-2578 C>$ A (\%) & & & & & 0.253 \\
AA & $6(5.56)$ & $6(3.68)$ & $11(7.43)$ & $1(2.56)$ & \\
AC & $47(43.52)$ & $59(36.20)$ & $55(37.16)$ & $21(53.85)$ & \\
CC & $55(50.93)$ & $98(60.12)$ & $82(55.41)$ & $17(43.59)$ & \\
$-1154 G>A(\%)$ & & & & & 0.042 \\
AA & $1(0.93)$ & $6(3.68)$ & $2(1.35)$ & $1(2.56)$ & \\
AG & $36(33.33)$ & $37(22.70)$ & $40(27.03)$ & $18(46.15)$ & \\
GG & $71(65.74)$ & $120(73.62)$ & $106(71.62)$ & $20(51.28)$ & \\
$-460 T>C(\%)$ & & & & & 0.230 \\
CC & $7(6.48)$ & $6(3.68)$ & $11(7.43)$ & $1(2.56)$ & \\
CT & $47(43.52)$ & $59(36.20)$ & $55(37.16)$ & $21(53.85)$ & \\
TT & $54(50.00)$ & $98(60.12)$ & $82(55.41)$ & $17(43.59)$ & \\
$+405 G>C(\%)$ & & & & & \\
CC & $17(15.74)$ & $35(21.47)$ & $29(19.59)$ & $6(15.38)$ & \\
CG & $58(53.70)$ & $78(47.85)$ & $74(50.00)$ & $23(58.97)$ & \\
GG & $33(30.56)$ & $50(30.67)$ & $45(30.41)$ & $10(25.64)$ & \\
\hline
\end{tabular}


Table 3 Frequency distribution of VEGF genotypes in different smoking status of lung cancer

\begin{tabular}{cllll}
\hline Variables & No & $<25$ & $>=25$ & $\begin{array}{l}P \\
(n=235)\end{array}$ \\
& $(n=52)$ & $(n=171)$ & value \\
\hline$-2578 C>$ A (\%) & & & & 0.494 \\
AA & $11(4.68)$ & $2(3.85)$ & $11(6.43)$ & \\
AC & $88(37.45)$ & $19(36.54)$ & $75(43.86)$ & \\
CC & $136(57.87)$ & $31(59.61)$ & $85(49.71)$ & \\
$-1154 G>$ A (\%) & & & & 0.060 \\
AA & $3(1.28)$ & $1(1.92)$ & $6(3.51)$ & \\
AG & $59(25.11)$ & $12(23.08)$ & $60(35.09)$ & \\
GG & $173(73.61)$ & $39(75.00)$ & $105(61.40)$ & \\
$-460 T>C(\%)$ & & & & 0.481 \\
CC & $11(4.68)$ & $2(3.85)$ & $12(7.02)$ & \\
CT & $89(37.87)$ & $19(36.54)$ & $74(43.27)$ & \\
TT & $135(57.45)$ & $31(59.61)$ & $85(49.71)$ & \\
$+405 G>C(\%)$ & & & & 0.493 \\
CC & $46(19.57)$ & $8(15.38)$ & $33(19.30)$ & \\
CG & $125(53.19)$ & $29(55.77)$ & $79(46.20)$ & \\
GG & $64(27.24)$ & $15(28.85)$ & $59(34.50)$ & \\
\hline
\end{tabular}

multivariate analysis (Table 4). As the four VEGF gene polymorphisms are in linkage disequilibrium, haplotype analyses were conducted to assess the combined effect of the four SNPs on lung cancer survival (Table 5). Six common haplotypes (CGTG, 26.55\%; AACG, 5.65\%; AGCG, 4.37\%; AGTG, 4.83\%; CGCG, 4.99\%; CGTC, $35.36 \%)$ were inferred. Unfortunately, no significant independent association was found for haplotypes and survival.

Table 4 Survival analysis according to four VEGF gene polymorphisms

\begin{tabular}{lll}
\hline Variables & OR $(95 \%$ Cl) & $\boldsymbol{P}$ value \\
\hline-2578 C > A (\%) & & 0.997 \\
AA vs CC & $0.525(0.217-1.270)$ & 0.156 \\
AC vs CC & $0.965(0.633-1.471)$ & 0.304 \\
-1154 G > A (\%) & & 0.938 \\
AA vs GG & $0.679(0.187-2.460)$ & 0.568 \\
AG vs GG & $0.974(0.621-1.529)$ & 0.66 \\
-460 T > C (\%) & & 0.998 \\
CC vs TT & $0.471(0.199-1.117)$ & 0.091 \\
CT vs TT & $0.952(0.624-1.453)$ & 0.234 \\
+405 G > C (\%) & & 0.918 \\
CC vs GG & $1.402(0.765-2.567)$ & 0.267 \\
CG vs GG & $1.068(0.677-1.686)$ & 0.626 \\
\hline
\end{tabular}

\section{Discussion}

VEGF is a highly polymorphic gene, and numerous evidence has revealed that VEGF SNPs are associated with cancer risk and prognosis. In our previous study, we found that $\mathrm{C}$ allele of VEGF $+405 \mathrm{G}>\mathrm{C}$ genotype was significantly associated with increased risk of lung cancer [14]. In this study, we found that VEGF -1154G > A polymorphism was significantly associated with tumor stages, but all four tested VEGF gene polymorphisms had no significant effect on survival.

It is reported that the $-1154 \mathrm{~A} / \mathrm{A}$ and G/A genotype were linked with low VEGF expression, and the -1154A/ A polymorphism also related with poor vascularization in patients with lung cancer [13]. In this study, our data showed that $-1154 \mathrm{G}>\mathrm{A}$ polymorphism was significantly associated with tumor stages. Specifically, the proportion of A allele (AA and AG) was higher in the stage IV group compared to other stage groups. This result seemed to contradict with the established conclusion, because A allele in -1154G $>\mathrm{A}$ is believed to associate with low VEGF expression and poor vascularization. However, it is also possible that A allele might slow down cancer progression and thus patients become aware of the disease later, when their cancer progresses further. In addition, we found that there was a strong trend between presence of A allele for $-1154 \mathrm{G}>\mathrm{A}$ and smoking for $>25$ years $(p=0.06)$. It could be that cancer progresses more slowly in these patients and they develop disease after longer period of smoking. Heist et al reported that patients with lung cancer carrying the variant $\mathrm{C}$ allele of the VEGF $+405 \mathrm{G}>\mathrm{C}$ polymorphism had significantly improved survival [15]. Our previous study showed that $\mathrm{C}$ allele of $+405 \mathrm{G}>\mathrm{C}$ was significantly associated with increased risk of lung cancer in males [14]. However, no association between the $+405 \mathrm{G}>\mathrm{C}$ polymorphism and survival was found in this study. In addition, VEGF $-2578 \mathrm{C}>\mathrm{A}$ and $-1154 \mathrm{G}>\mathrm{A}$ were found to have a marked impact on the survival of breast cancer $[16,17]$, but our study failed to find any association between these two SNPs and the survival of lung cancer. It is generally accepted that the ethnicity of study subjects is a crucial factor for interpreting genetic polymorphism studies [18]. The population of our study is Chinese, which is different from the cited studies. Therefore, the inconsistent findings between our study and other studies might attribute to the ethnic differences. Finally, it is worthy to point out that $-460 \mathrm{C} / \mathrm{C}$ polymorphism seemed to relate with survival (OR, 0.471; 95\% CI, 0.199-1.117) but the difference did not reach significance $(p=0.091)$. This OR could have been more significant in a larger cohort of patients. Importantly, there is also a trend for association between AACG haplotype and survival $(p=$ 0.058; OR, 0.870; 95\% CI, 0.753-1.004). This is interesting because these patients have A allele for $-1554 \mathrm{G}>\mathrm{A}$ 
Table 5 Survival analysis according to common haplotypes of four VEGF gene polymorphisms

\begin{tabular}{|c|c|c|c|}
\hline $\begin{array}{l}\text { Haplotypes }(-2578 \mathrm{C}>\mathrm{A} /-1154 \mathrm{G}> \\
\mathrm{A} /-460 \mathrm{~T}>\mathrm{C} /+405 \mathrm{G}>\mathrm{C})\end{array}$ & $\begin{array}{l}\text { Haplotype } \\
\text { frequency (\%) }\end{array}$ & OR $(95 \% \mathrm{Cl})$ & $\begin{array}{l}P \\
\text { value }\end{array}$ \\
\hline CGTG & 26.55 & 1 & \\
\hline AACG & 5.65 & $\begin{array}{l}0.870 \\
(0.753- \\
1.004)\end{array}$ & 0.058 \\
\hline AGCG & 4.37 & $\begin{array}{l}0.916 \\
(0.776- \\
1.081)\end{array}$ & 0.300 \\
\hline AGTG & 4.83 & $\begin{array}{l}0.922 \\
(0.797- \\
1.067)\end{array}$ & 0.276 \\
\hline CGCG & 4.99 & $\begin{array}{l}0.905 \\
(0.782- \\
1.047)\end{array}$ & 0.179 \\
\hline CGTC & 35.36 & $\begin{array}{l}1.021 \\
(0.946- \\
1.101)\end{array}$ & 0.590 \\
\hline
\end{tabular}

All those frequency $<0.03$ were ignored in the analysis

and $\mathrm{G}$ allele for $+405 \mathrm{G}>\mathrm{C}$ that are associated with lower vascularization and lower risk of developing lung cancer, respectively.

\section{Conclusions}

Our data revealed that VEGF polymorphisms may relate to stage but not survival of lung cancer in Chinese population. Our findings should spur the interest of additional investigation of gene polymorphisms in VEGF as well as the other angiogenesis pathway associated with lung cancer risk and outcomes.

\section{Abbreviations}

VEGF-A: Vascular endothelial growth factor A; SNP: Single nucleotide polymorphism; UTR: Untranslated regions; PCR: Polymerase chain reaction; RFLP: Restriction fragment length polymorphism; OS: Overall survival

\section{Acknowledgments}

Not Applicable.

\section{Authors' contributions}

$C J L$ and $Y G$ conceived and designed the experiments. CJL, XTZ, ZFZ and YG performed the experiments. CJL analyzed the data. CJL wrote the paper. YG revised the paper. All authors had reviewed and agreed on the contents of this paper.

\section{Funding}

The study is supported by Natural Science Foundation of Hebei Province (No. C2009001199). The funding body played no role in the design of the study and collection, analysis, and interpretation of data and in writing the manuscript.

\section{Availability of data and materials}

All data generated or analyzed during this study are included in this published article.

\section{Ethics approval and consent to participate}

This study was approved by the Ethics Committee of the Fourth Affiliated Hospital of Hebei Medical University. Written informed consent was obtained from all participants.

\section{Consent for publication}

Not Applicable.

\section{Competing interests}

The authors declare no competing interests.

\section{Author details}

${ }^{1}$ Department of Thoracic Surgery, the Fourth Hospital of Hebei Medical University, 12 Jiankang Road, Shijiazhuang 050000, China. ²Department of Thoracic Surgery, the Third Hospital of Hebei Medical University,

Shijiazhuang, China.

Received: 7 May 2019 Accepted: 20 April 2020

Published online: 30 April 2020

\section{References}

1. Scappaticci FA. Mechanisms and future directions for angiogenesis-based cancer therapies. J Clin Oncol. 2002;20(18):3906-27.

2. Potente M, Gerhardt $\mathrm{H}$, Carmeliet P. Basic and therapeutic aspects of angiogenesis. Cell. 2011;146(6):873-87.

3. Zhao Y, Adjei AA. Targeting angiogenesis in Cancer therapy: moving beyond vascular endothelial growth factor. Oncologist. 2015;20(6):660-73.

4. Ferrara N, Adamis AP. Ten years of anti-vascular endothelial growth factor therapy. Nat Rev Drug Discov. 2016;15(6):385-403.

5. Lee SH, Jeong D, Han YS, Baek MJ. Pivotal role of vascular endothelial growth factor pathway in tumor angiogenesis. Ann Surg Treat Res. 2015; 89(1):1-8.

6. Datta M, Via LE, Kamoun WS, Liu C, Chen W, Seano G, et al. Anti-vascular endothelial growth factor treatment normalizes tuberculosis granuloma vasculature and improves small molecule delivery. Proc Natl Acad Sci U S A. 2015;112(6):1827-32.

7. Barr MP, Gray SG, Gately K, Hams E, Fallon PG, Davies AM, et al. Vascular endothelial growth factor is an autocrine growth factor, signaling through neuropilin-1 in non-small cell lung cancer. Mol Cancer. 2015;14:45.

8. Yuan A, Yu CJ, Chen WJ, Lin FY, Kuo SH, Luh KT, Yang PC. Correlation of total VEGF mRNA and protein expression with histologic type, tumor angiogenesis, patient survival and timing of relapse in non-small-cell lung cancer. Int J Cancer. 2000;89(6):475-83.

9. Kaya A, Ciledag A, Gulbay BE, Poyraz BM, Celik G, Sen E, Savas H, Savas I. The prognostic significance of vascular endothelial growth factor levels in sera of non-small cell lung cancer patients. Respir Med. 2004;98(7):632-6.

10. Dudek AZ, Mahaseth $\mathrm{H}$. Circulating angiogenic cytokines in patients with advanced non-small cell lung cancer: correlation with treatment response and survival. Cancer Investig. 2005;23(3):193-200.

11. Jain L, Vargo CA, Danesi R, Sissung TM, Price DK, Venzon D, Venitz J, Figg WD. The role of vascular endothelial growth factor SNPs as predictive and prognostic markers for major solid tumors. Mol Cancer Ther. 2009:8(9):2496-508.

12. Schneider BP, Radovich M, Miller KD. The role of vascular endothelial growth factor genetic variability in cancer. Clin Cancer Res. 2009;15(17): 5297-302.

13. Koukourakis MI, Papazoglou D, Giatromanolaki A, Bougioukas G, Maltezos E, Sivridis E. VEGF gene sequence variation defines VEGF gene expression status and angiogenic activity in non-small cell lung cancer. Lung Cancer. 2004:46(3):293-8

14. Liu C, Zhou X, Gao F, Qi Z, Zhang Z, Guo Y. Correlation of genetic polymorphism of vascular endothelial growth factor gene with susceptibility to lung cancer. Cancer Gene Ther. 2015;22(6):312-6.

15. Heist RS, Zhai R, Liu G, Zhou W, Lin X, Su L, et al. VEGF polymorphisms and survival in early-stage non-small-cell lung cancer. J Clin Oncol. 2008;26(6): 856-62.

16. Smith KC, Bateman AC, Fussell HM, Howell WM. Cytokine gene polymorphisms and breast cancer susceptibility and prognosis. Eur J Immunogenet. 2004:31(4):167-73.

17. Kidd LR, Brock GN, VanCleave $\Pi$, Benford ML, Lavender NA, Kruer TL, Wittliff $J$. Angiogenesis-associated sequence variants relative to breast cancer recurrence and survival. Cancer Causes Control. 2010;21(10):1545-57. 
18. Winkler S, König IR, Lohmann-Hedrich K, Vieregge P, Kostic V, Klein C. Role of ethnicity on the association of MAPT H1 haplotypes and subhaplotypes in Parkinson's disease. Eur J Hum Genet. 2007;15(11):1163-8.

\section{Publisher's Note}

Springer Nature remains neutral with regard to jurisdictional claims in published maps and institutional affiliations.

Ready to submit your research? Choose BMC and benefit from:

- fast, convenient online submission

- thorough peer review by experienced researchers in your field

- rapid publication on acceptance

- support for research data, including large and complex data types

- gold Open Access which fosters wider collaboration and increased citations

- maximum visibility for your research: over $100 \mathrm{M}$ website views per year

At BMC, research is always in progress.

Learn more biomedcentral.com/submissions 